\title{
ANALISIS PERBANDINGAN PREDIKSI KONDISI FINANCIAL DISTRESS DENGAN MENGGUNAKAN MODEL ALTMAN, SPRINGATE DAN ZMIJEWSKI
}

\author{
Fitri Listyarini \\ Universitas Maritim Raja Ali Haji \\ flistyarini@gmail.com
}

\begin{abstract}
This study aims to: 1) Determine the accuracy of the Altman model, the springate model and the zmijewski model in predicting financial distress conditions in manufacturing companies in Indonesia, 2) To find out the most accurate prediction models in predicting financial distress conditions in manufacturing companies in Indonesia. This study compares three financial distress prediction models, the Altman, Springate and Zmijewski models. The population of this study is the financial statements of manufacturing companies listed on the Indonesia Stock Exchange for the period 20112014. The sampling technique is pair matching sampling with a total sample of 28 companies, consisting of 14 companies experiencing financial distress and 14 companies not experiencing financial distress. Comparisons of the three financial distress prediction models are made by analyzing the accuracy of each model based on the company's real conditions. The results show that the zmijewski model is the most accurate model for predicting financial distress in manufacturing companies in Indonesia because it has the highest level of accuracy compared to other models, which is $100 \%$, followed by the Springate model which has an accuracy rate of $89.29 \%$ and the Altman model by $75 \%$.
\end{abstract}

Keywords: Financial distress, Altman Model, Springate Model, Zmijewski Model

\section{PENDAHULUAN}

Pada umumnya, setiap perusahaan didirikan dengan tujuan untuk memaksimalkan keuntungan, menjalankan fungsi-fungsi sosial dalam masyarakat serta dapat bertahan hidup dalam persaingan dan berkembang dalam jangka waktu yang tidak terbatas.
Dengan kata lain, perusahaan didirikan dengan asumsi going concern, yakni perusahaan mempu mempertahankan usahanya dalam jangka waktu yang panjang dan diharapkan tidak akan dilikuidasi dalam jangka waktu pendek (Hadi \& Anggraeni, 2008; Rismawaty, 2012). Namun dalam praktiknya asumsi 
tersebut tidak selamanya berjalan lancar. Seringkali perusahaan yang telah beroperasi dalam kurun waktu tertentu terpaksa bubar atau dilikuidasi karena terus berada dalam kesulitan keuangan (financial distress) disetiap periodenya, baik itu karena terjadinya kerugian akibat piutang tak tertagih, pembayaran kredit yang tersendat dan lain lain. Hal ini pada akhirnya akan merujuk pada kebangkrutan (Rismawaty, 2012). Platt \& Platt (2002), Ramadhani \& Lukviarman (2009) menyebutkan dalam penelitiannya bahwa, financial distress merupakan tahapan penurunan kondisi keuangan suatu perusahaan sebelum terjadinya kebangkrutan ataupun likuidasi. Terjadinya financial distress tentu akan merugikan banyak pihak yang berkaitan dengan perusahaan. Oleh karena itu haruslah dilakukannya upaya-upaya untuk mencegah kondisi financial distress. Ramadhani \& Lukviarman (2009) memaparkan dalam penelitiannya bahwa untuk mengatasi dan meminimalisir terjadinya kebangkrutan, perusahaan dapat mengawasi kondisi keuangan dengan menggunakan teknik-teknik analisis laporan keuangan. Dengan begitu maka dapat diketahui kondisi dan perkembangan financial perusahaan, kelemahan dan potensi kebangkrutan perusahaan. Hal ini terjadi karena laporan keuangan dapat dijadikan sebagai informasi baik mengenai posisi keuangan perusahaan maupun prestasi manajemen pada periode tertentu, laporan keuangan juga dapat dijadikan acuan dalam pengambilan keputusan. (Purnajaya \& Merkusiwati, 2014).Beberapa model prediksi yang telah dikembangkan untuk menjadi alat prediksi kondisi financial distress diantaranya adalah yang dikemukakan oleh Altman (1968), Springate (1978) dan Zmijewski (1984). Model Altman yang disebut dengan Altman Z-Score merupakan salah satu alat yang dapat memprediksi kebangkrutan berdasarkan 5 rasio keuangan dengan menggunakan analisis multiple diskriminant Analysis (MDA). Model Springate (1978) menggunakan juga menggunakan teknik analisis Multiple Discriminant Analysis dengan menggunakan sampel perusahaan di Kanada. Springate memprediksi kebangkrutan dengan menggunakan 4 rasio keuangan. Zmijewski (1983) yaitu profitabilitas, leverage dan likuiditas. Metode pemilihan sampel yang digunakan 
adalah random sampling, jadi perusahaan yang dipisahkan menjadi dua kategori yaitu distress dan nondistress tidak harus sama jumlahnya (Rismawaty, 2012). Penelitian ini bertujuan untuk mengetahui berapakah tingkat akurasi model Altman, Springate dan Zmijewski dalam memprediksi kondisi financial distress

\section{TELAAH LITELATUR}

Financial Distress

Ramadhani \& Lukviarman (2009) dalam penelitiannya menyebutkan bahwa financial distress (kesulitan keuangan) terjadi sebelum kebangkrutan benar-benar terjadi. Pengertian financial distress didefinisikan oleh Ross, Westerfield, \& Jaffe (2003) sebagai ketidakmampuan perusahaan dalam memenuhi kewajiban-kewajibannya (insolvency). Ada dua kriteria yakni stock-based insolvency dan flow-base insolvency. Stock-based insolvency ialah suatu kondisi dimana laporan posisi keuangan perusahaan mengalami ekuitas negatif (negative net worth), sedangkan flowbase insolvency merupakan kondisi dimana arus kas operasi (operating cash flow) tidak dapat memenuhi kewajiban- pada perusahaan manufaktur di Indonesia serta model manakah yang paling akurat. Dengan diketahuinya model dengan akurasi tertinggi, maka perusahaan atau investor dapat mengaplikasikan model tersebut untuk memprediksi kondisi financial distress pada perusahaan manufaktur di Indonesia.

kewajiban lancar perusahaan. Penelitian yang dilakukan oleh Hofer (1980) dan Whitaker (1999) dalam Luciana (2006) mendefinisikan financial distress sebagai suatu kondisi perusahaan mengalami laba bersih (net income) negatif selama beberapa tahun. Jadi, dapat disimpulkan bahwa financial distress adalah kondisi penurunan keuangan yang tercermin dalam laporan keuangan maupun aktivitas operasional perusahaan yang terjadi sebelum perusahaan mengalami kebangkrutan.

\section{Model Prediksi Altman}

Altman pada tahun 1968 menggunakan metode multivariate discriminant analysis (MDA) dalam penelitiannya. Altman menggunakan teknik pair matching dalam pemilihan sampelnya. Pair matching yang digunakan Altman 
menggunakan 2 kriteria, yaitu industri yang sama dan besarnya perusahaan (total aset) yang sama. Altman mengambil sampel 66 perusahaan Amerika, 33 perusahaan manufaktur yang bangkrut pada periode 1946-1965 dan 33 perusahaan yang tidak bangkrut. Altman menyusun 22 rasio keuangan yang paling memungkinkan dan mengelompokkannya kedalam 5 kategori yaitu likuiditas, profitabilitas, solvabilitas, leverage dan kinerja. Kemudian dengan menggunakan teknik MDA, Altman mendapatkan 5 rasio keuangan untuk memprediksi kondisi financial distress. Altman merevisi model Z-Score dengan melakukan beberapa penyesuaian. Revisi ini dilakukan agar model yang dia ciptakan dapat digunakan tidak hanya untuk perusahaan manufaktur yang go public tetapi untuk semua perusahaan private maupun go public. Dalam revisinya, Altman mengahadirkan 2 buah model baru yang juga dapat digunakan untuk perusahaan private dan untuk perusahaan sektor non-manufaktur (Altman, 2000).

$$
Z^{\prime}=0.717 \mathrm{WCTA}+0.847 \mathrm{RETA}+3.107 \mathrm{EBITTA}+0.420 \mathrm{TETL}+0.998 \mathrm{SATA}
$$

Keterangan:

Jika nilai Z' $<1.23$ maka termasuk perusahaan yang mengalami financial dstress. Jika nilai $1.23<Z^{\prime}<2.9$ maka termasuk gray area

Jika nilai Z'> 2.9 maka termasuk perusahaan yang tidak mengalami financial distress.

Model Prediksi Springate

Springate membuat model prediksi financial distress pada tahun 1978. Dalam pembuatannya, Springate menggunakan metode yang sama dengan Altman yaitu multiple discriminant analysis (MDA). Seperti Altman, pada awalnya Springate (1978) mengumpulkan rasio-rasio keuangan populer yang bisa dipakai untuk memprediksi financial distress. Jumlah rasio awalnya yaitu 19 rasio. Kemudian Springate memilih 4 rasio yang dipercaya bisa membedakan antara perusahaan yang mengalami distress dan yang tidak distress. Springate menggunakan sample 20 perusahaan bangkrut kemudian dipasangkan dengan 
20 perusahaan yang tidak bangkrut

(Sondakh, Murni, \& Mandagie, 2014;
Boritz, Kennedy \& Sun, 2007) di mana dengan rumus sebagai berikut:

$$
\mathrm{Z}=1.03 \mathrm{WCTA}+3.07 \mathrm{EBITTA}+0.66 \mathrm{EBTCL}+0.4 \mathrm{SATA} .
$$

Keterangan:

Jika nilai $Z<0.862$ maka termasuk perusahaan yang mengalami financial distress.

Jika nilai Z > 0.862 maka termasuk perusahaan yang tidak mengalami financial distress.

\section{Model Prediksi Zmijewski}

Berbeda dengan penelitian Altman dan Springate, Zmijewski menggunakan teknik random sampling dalam penelitiannya. Dalam penelitiannya, Zmijewski mensyaratkan bahwa karakteristik populasi harus ditentukan. Sebelum data dikumpulkan, populasi harus benar-benar diidentifikasi dan asumsi financial distress harus dioperasionalisasikan dengan jelas.
Sampel yang digunakan Zmijewski berjumlah 840 perusahaan, terdiri dari 40 perusahaan yang mengalami financial distress dan 800 yang tidak mengalami financial distress. Data diperoleh dari Compustat Annual Industrial File. Data dikumpulkan dari tahun 1972-1978. Metode statistik yang digunakan Zmijewski adalah regresi logit (Zmijewski, 1984).

$$
X=-4.3-4.5 \text { NITA }+5.7 \text { TLTA }-0.004 \text { CACL }
$$

Keterangan:

Jika nilai $\mathrm{X}>0$ maka termasuk perusahaan yang mengalami financial distress. Jika nilai $\mathrm{X}<0$ maka termasuk perusahaan yang tidak mengalami financial distress.

\section{METODOLOGI PENELITIAN}

Objek dan ruang lingkup penelitian yang di lakukan penulis lakukan pada perusahaan manufaktur yang terdaftar di Bursa Efek Indonesia pada tahun 2011-
2014. Objek penelitian ini adalah laporan keuangan akhir tahun setiap perusahaan manufakur. Variabel adalah suatu simbol yang berisi suatu nilai (Jogiyanto, 2008). Variabel dalam 
penelitian ini adalah variabel yang Zmijewski. Variabel-variabel yang digunakan oleh model-model prediksi digunakan oleh ketiga model tersebut financial distress, dalam hal ini adalah adalah

model Altman, Springate dan

Model Altman

$$
Z^{\prime}=0.717 \text { WCTA + 0.847 RETA + 3.107 EBITTA + 0.420 TETL + 0.998 SATA }
$$

Keterangan:

$Z^{\prime} \quad=\quad$ overall index

WCTA $=\quad$ working capital $/$ total asset

RETA $=\quad$ retained earning $/$ total asset

EBITTA $=$ earning before interest and taxes / total asset

TETL $=$ book value of equity / book value of total liabilities

SATA $=\quad$ sales $/$ total asset

Model Springate

$$
\mathrm{Z}=1.03 \mathrm{WCTA}+3.07 \mathrm{EBITTA}+0.66 \mathrm{EBTCL}+0.4 \mathrm{SATA}
$$

Keterangan:

$\mathrm{Z}=$ overall index

WCTA = working capital $/$ total asset

EBITTA = earningt before interest and taxes / total asset

EBTCL = earning before taxes/current liabilities

SATA = sales $/$ total asset

Model Zmijewski

$$
\mathrm{X}=-4.3-4.5 \mathrm{NITA}+5.7 \text { TLTA }-0.004 \mathrm{CACL}
$$

Keterangan:

$\mathrm{X}=$ overall index

NITA $=$ net income $/$ total asset

TLTA $=\quad$ total liabilities $/$ total asset

$\mathrm{CACL}=\quad$ current asset $/$ current liabilities 
Metode pengumpulan data dalam penelitian ini adalah teknik pengambilan basis data, yaitu dengan mendapatkan data arsip sekunder (Jogiyanto, 2008). Data sekunder adalah data yang diterbitkan oleh organisasi yang bukan pengolahnya (Suliyanto, 2009). Data yang dibutuhkan dalam penelitian ini adalah laporan keuangan tahunan perusahaan manufaktur yang terdaftar di Bursa Efek Indonesia tahun tutup buku 31 Desember. Data dalam penelitian ini diperoleh dari website Bursa Efek Indonesia www.idx.co.id. Populasi merupakan keseluruhan objek yang karakteristiknya hendak kita uji (Suliyanto, 2009). Populasi dalam penelitian ini adalah seluruh perusahaan manufaktur yang terdaftar di Bursa Efek Indonesia pada tahun 2011-2014. Alasan pemilihan sektor manufaktur adalah dikarenakan model financial distress yang diteliti memiliki variabel yang sesuai dengan karakteristik perusahaan manufaktur. Sampel adalah bagian dari populasi yang karakteristiknya hendak kita uji (Suliyanto, 2009). Teknik sampling yang digunakan peneliti adalah teknik purposive sampling dimana pengambilan sampel ini dilakukan dengan mengambil sampel dari populasi bedasarkan kriteria tertentu (Jogiyanto, 2008). Adapun kriteria sampel yang ditentukan dalam penelitian ini adalah kriteria khusus dan kriteria umum. Berikut adalah kriteria umum yang ditetapkan adalah perusahaan mempublikasikan data laporan keuangan pada tahun 2011- 2014, Perusahaan mempublikasikan laporan keuangan dengan tahun fiskal berakhir pada bulan Desember, Perusahaan mempublikasikan laporan keuangan yang disajikan dengan mata uang rupiah. Selain kriteria umum penelitian ini juga menetapkan kriteria khusus yang harus dipenuhi untuk tujuan mengkategorikan sampel. Sampel dibagi menjadi 2 kategori yaitu perusahaan yang mengalami financial distress dan yang tidak mengalami financial distress. Sampel dipilih dengan teknik pair matching. Teknik pair matching dilakukan dengan cara masing-masing item pada sampel dipadankan dengan item sampel kontrol dengan karakteristik yang sama sedangkan yang berbeda hanya kategori (Jogiyanto, 2008). Berikut adalah kriteria financial distress menurut beberapa peneliti: 
Hofer (1980) dan Whitaker (1999) dalam Luciana (2006) mendefinisikan financial distress sebagai suatu kondisi perusahaan yang mengalami laba bersih (net income) negatif selama beberapa tahun. Christianti (2013) mengkategorikan financial distress kedalam dua kondisi, yaitu ketika perusahaan memiliki ekuitas negatif yang berarti total utang melebihi total aset yang dimiliki perusahaan (TL>TA) dan perusahaan tersebut memiliki net income negatif selama 2 tahun berturutturut. Sehingga dapat disimpulkan bahwa karakteristik financial distress adalah sebagai berikut perusahaan tersebut memiliki laporan neraca dengan ekuitas negatif. perusahaan tersebut memiliki laporan laba rugi dengan net income yang bernilai negatif selama beberapa tahun. Karakteristik yang disebutkan di atas merupakan kriteria khusus yang digunakan untuk memenuhi kriteria sampel kategori 1 perusahaan yang mengalami financial distress. Untuk memenuhi krieria sampel kategori dua perusahaan yang tidak mengalami financial distress, maka ditetapkan kriteria khusus sebagai berikut:
1. Perusahaan tersebut tidak memiliki laporan neraca dengan ekuitas negatif.

2. Perusahaan tersebut tidak memiliki laporan laba rugi dengan net income yang bernilai negatif selama beberapa tahun.

3. Perusahaan berasal dari tahun yang sama dengan perusahaan kategori 1.

4. Perusahaan berasal dari sektor yang sama dengan perusahaan dengan kategori 1.

5. Memiliki rata-rata total aset yang relatif sama dengan total aset perusahaan kategori 1 .

Dalam penelitian ini data diolah dengan menggunakan aplikasi SPSS 21. Sebelum melakukan pengujian hipotesis, maka langkah pertama adalah menguji apakah kriteria khusus sampel sudah matched atau belum, maka perlu dilakukan uji beda dua rata-rata. Uji ini digunakan untuk membandingkan ratarata dari dua sampel dimana sampelsampel tersebut saling bebas atau tidak memiliki hubungan. Dalam kasus ini digunakan untuk menguji apakah ada perbedaan rata- rata total aset antara 2 kategori sampel. Jika data berdistribusai 
normal, maka uji yang digunakan adalah uji independen sampel t-test (Trihendardi, 2013). Namun, jika data berdistribusi tidak normal, maka uji yang digunakan adalah uji Mann Whitney (Trihendradi, 2013). Hasil yang akan dilihat dalam kedua uji ini dengan menggunakan tingkat signifikansi $95 \%$ apabila signifikansi > 0.025 maka keputusannya adalah Ho diterima. Maka tidak ada perbedaan antara rata-rata total aset pada sampel kategori 1 dan kategori 2. apabila signifikansi $<0.025$ maka keputusannya adalah Ho ditolak. Maka, ada perbedaan antara rata-rata total aset sampel kategori 1 dan kategori 2. Berikut adalah tahapan-tahapan yang dilakukan dalam penelitian ini:

1. Mengolah data dengan menggunakan microsoft excel untuk mengetahui seluruh sampel yang akan diproses.

2. Melakukan uji beda dua rata-rata pada seluruh sampel yang bertujuan untuk memastikan bahwa seluruh kriteria match antara kriteria sampel kategori 1 (perusahaan yang mengalami financial distress) dan sampel kategori 2 (perusahaan yang tidak mengalami financial distress).

3. Mengolah data untuk mendapatkan statistik deskriptif dengan menggunakan SPSS 21.

4. Menghitung variabel dengan menggunakan masing-masing model, yaitu model Altman, Springate dan Zmijewski. Dari setiap perhitungan maka dapat ditentukan prediksi model terhadap perusahaan apakah akan mengalami financial distress atau tidak.

5. Membandingkan hasil yang diperoleh model dengan kondisi real.

6. Menghitung tingkat akurasi tiap model untuk menemukan model prediksi kondisi financial distress terbaik. Model dengan tingkat akurasi paling tinggi adalah model prediksi kondisi financial distress terbaik.

Eror tipe I adalah kesalahan yang terjadi jika model memprediksi sampel tidak mengalami distress padahal kenyataannya mengalami distress. Eror tipe II adalah kesalahan yang terjadi jika model memprediksi sampel mengalami distress padahal kenyataannya tidak 
mengalami distress (Altman, 2000). sebagai berikut:

Tingkat eror dihitung dengan cara

Error Tipe I = (Jumlah Kesalahan Tipe 1) / (Jumlah Sampel Kelompok 1) x $100 \%$

Error Tipe $2=($ Jumlah Kesalahan Tipe 1) / (Jumlah Sampel Kelompok 2) x 100\%

Tingkat error merupakan deskripsi model mana yang paling akurat adalah kesalahan yang terjadi pada tiap model. dengan menggunakan total akurasi. Kemudian untuk mengetahui Total akurasi didapat dari:

Total Akurasi $=($ Jumlah Sampel benar $) /($ Jumlah Sampel $) \times 100 \%$

\section{PEMBAHASAN}

Penelitian ini menggunakan populasi ditentukan. Sehingga didapatkan 28 seluruh perusahaan manufaktur yang sampel, dimana 14 adalah perusahaan terdaftar di Bursa Efek Indonesia yang mengalami financial distress dan periode 2011-2014. Pemilihan sampel 14 perusahaan adalah perusahaan yang menggunakan teknik pair matching tidak mengalami financial distress.

sampling dengan kriteria yang telah

Tabel 1 Pengujuan Mann Whitney

\begin{tabular}{lr} 
& \multicolumn{1}{c}{ Total Assets } \\
Mann-Whitney U & 98,000 \\
Wilcoxon W & 203,000 \\
Z &, 000 \\
Asymp. Sig. (2-tailed) & 1,000 \\
Exact Sig. [2*(1-tailed Sig.)] & $1,000^{\mathrm{b}}$ \\
\hline
\end{tabular}


Dapat hasil tersebut dapat di lihat bahwa nilai Sig (2-tailed) yang didapat adalah sebesar 1,000 dan nilai tersebut lebih besar dari 0,025. Hal ini menunjukan sehingga dapat di katakana dikatakan di mana berarti sampel yang digunakan sudah memenuhi semua kriteria pair matching dan dapat diproses untuk tahap penelitian selanjutnya. Berdasarkan pada tabel 2, terlihat bahwa sebanyak 14 perusahaan dengan kondisi real mengalami financial distress dengan menggunakan model Altman memprediksi sebanyak 14 perusahaan tersebut dengan tepat. Artinya, dalam memprediksi bahwa tidak ada perbedaan antara ratarata total aset pada sampel kategori 1 dan kategori 2. Oleh karena itu dikatakan bahwa dengan ini menunjukan bahwa di mana perusahaan kondisi real mengalami financial distress model Altman tidak menghasilkan salah prediksi sehingga error tipe I sangat rendah yaitu bernilai 0\%. Sedangkan untuk 14 perusahaan dengan kondisi real dapat di ketahui bahwa di mana tidak mengalami financial distress model Altman memprediksi 1 perusahaan yang mengalami financial distress 
Tabel 2 Jenis Perusahaan Dengan Berbagai Kategori

\begin{tabular}{|c|c|c|c|c|c|c|c|}
\hline \multirow{2}{*}{$\begin{array}{c}\text { Jenis } \\
\text { Perusahaan }\end{array}$} & \multirow{2}{*}{ Nama } & \multicolumn{2}{|c|}{ Altman } & \multicolumn{2}{|c|}{ Springate } & \multicolumn{2}{|c|}{ Zmijewski } \\
\hline & & $\mathbf{Z}$ & Kes & $\mathbf{Z}$ & Kes. & $\mathbf{X}$ & Kes \\
\hline \multirow{10}{*}{ Katagori 1} & UNTX & $-1,10$ & D & $-1,11$ & $\mathrm{D}$ & 7,72 & D \\
\hline & SIMM & $-5,21$ & D & $-2,70$ & D & 9,20 & D \\
\hline & SIMA & $-5,22$ & D & $-5,33$ & D & 6,92 & D \\
\hline & MYTX & 0,90 & D & 1,43 & D & 1,91 & D \\
\hline & SULI & $-1,62$ & D & $-0,93$ & D & 2,06 & D \\
\hline & JKSW & $-1,36$ & D & $-0,38$ & D & 9,81 & D \\
\hline & SIMA & $-1,54$ & D & $-0,72$ & D & 3,71 & D \\
\hline & MYTX & 0,02 & D & $-0,10$ & D & 1,79 & D \\
\hline & SULI & $-3,36$ & D & $-1,89$ & D & 5,21 & D \\
\hline & JKSW & $-1,31$ & D & $-0,13$ & D & 10,35 & D \\
\hline \multirow{18}{*}{ Katagori 2} & RMBA & 0,40 & D & $-0,38$ & D & 3,17 & D \\
\hline & MYTX & $-0,28$ & D & $-0,52$ & D & 2,50 & D \\
\hline & SCPI & 0,82 & D & 0,51 & D & 1,79 & D \\
\hline & JKSW & $-1,23$ & D & 0,22 & D & 9,39 & D \\
\hline & LPIN & 2,29 & GA & 1,21 & ND & $-3,22$ & $\mathrm{ND}$ \\
\hline & LMSH & 3,86 & $\mathrm{ND}$ & 2,05 & $\mathrm{ND}$ & $-2,44$ & $\mathrm{ND}$ \\
\hline & $\mathrm{KICI}$ & 2,49 & GA & 1,03 & ND & $-2,84$ & ND \\
\hline & MAIN & 1,86 & GA & 2,08 & ND & $-1,52$ & ND \\
\hline & HDTX & 0,82 & $\mathrm{D}$ & 0,21 & $\mathrm{D}$ & $-1,27$ & ND \\
\hline & EKAD & 3,52 & ND & 1,87 & ND & $-3,20$ & $\mathrm{ND}$ \\
\hline & KICI & 2,38 & GA & 1,17 & ND & $-2,72$ & $\mathrm{ND}$ \\
\hline & AKPI & 1,43 & GA & 0,55 & $\mathrm{D}$ & $-1,49$ & $\mathrm{ND}$ \\
\hline & DLTA & 6,18 & $\mathrm{ND}$ & 4,38 & ND & $-4,47$ & $\mathrm{ND}$ \\
\hline & DPNS & 5,21 & ND & 5,36 & ND & $-4,78$ & $\mathrm{ND}$ \\
\hline & MYOR & 2,23 & GA & 1,05 & $\mathrm{ND}$ & $-1,06$ & $\mathrm{ND}$ \\
\hline & тото & 2,92 & $\mathrm{ND}$ & 1,73 & ND & $-2,72$ & ND \\
\hline & KBLI & 3,48 & $\mathrm{ND}$ & 1,63 & ND & $-2,86$ & $\mathrm{ND}$ \\
\hline & APLI & 3,53 & ND & 1,19 & ND & $-3,47$ & ND \\
\hline
\end{tabular}

Perusahaan mengalami financial kondisi real tidak mengalami financial distress padahal sebenarnya tidak distress model Altman memiliki eror mengalami financial distress. Artinya, tipe II sebesar 7,14\%. Hal ini dalam memprediksi perusahaan dengan mengindikasikan bahwa model Altman 
mampu memprediksi kondisi keuangan perusahaan manufaktur. Namun, model Altman memiliki eror tipe II yang berada pada angka 7,14\% lebih besar daripada eror tipe I yang bernilai $0 \%$ mengindikasikan bahwa model Altman terlalu pesimis dalam menilai perusahaan. Jika investor mempercayai model Altman maka investor bisa kehilangan kesempatan untuk berinvestasi karena model Altman memprediksi perusahaan sehat kedalam kategori perusahaan yang mengalami kondisi keuangan, hal ini akan menimbulkan opportunity cost bagi investor. Kemudian terdapat 6 perusahaan yang masuk kedalam kategori gray area. Kondisi grey area menurut Altman (2000) adalah kondisi dimana perusahaan tidak diketahui apakah berada dalam kondisi mengalami kondisi financial distress ataupun tidak mengalami kondisi financial distres, karena pada area ini model Altman rentan menghasilkan salah klasifikasi. Dengan adanya 6 perusahaan yang berada kondisi grey area atau sebesar $21,42 \%$ menunjukkan bahwa model Altman masih kurang mampu untuk menentukan kondisi keuangan perusahaan secara umum dikarenakan masih banyak perusahaan yang tidak dapat digolongkan dalam kondisi mengalami kondisi financial distress ataupun tidak. Dengan adanya batas grey area yang ditentukan Altman, dan persentasi perusahaan yang berada digolongan ini cukup tinggi, maka akan menjadi keragu-raguan bagi investor saat menggunakan model Altman. Daerah 'ragu-ragu' ini akan menjadi peluang munculnya kesalahan dalam keputusan investasi. Hal ini sejalan tingkat total akurasi yang dihasilkan oleh model Altman sebesar $75 \%$, dimana masih ada peluang kesalahan yang lebih tinggi dibandingkan dengan 2 model lain yang dibandingkan pada penelitian ini dalam mengukur kondisi financial distress suatu perusahaan. Model Springate memprediksi 13 perusahaan dengan tepat. Dengan kata lain, terdapat 1 perusahaan diprediksi tidak mengalami financial distress padahal sebenarnya mengalami financial distress. Artinya, dalam memprediksi perusahaan dengan kondisi real mengalami financial distress model Springate memiliki error tipe I sebesar 7,14\%. Sedangkan untuk 14 perusahaan dengan kondisi real tidak mengalami financial distress model 
Springate kurang tepat dalam memprediksi 2 perusahaan. Dengan kata lain, 2 perusahaan tersebut diprediksi mengalami financial distress padahal sebenarnya tidak mengalami financial distress. Artinya, dalam memprediksi perusahaan dengan kondisi real tidak mengalami financial distress model Springate memiliki eror tipe II sebesar 14,29\%. Serupa dengan model Altman, tingginya error tipe II dibanding error tipe I mengindikasikan bahwa model Springate terlalu pesimis dalam menilai perusahaan. Jika investor mempercayai model Springate maka investor bisa kehilangan kesempatan untuk berinvestasi karena model Springate memprediksi perusahaan sehat kedalam kategori perusahaan yang mengalami kondisi keuangan, hal ini akan menimbulkan opportunity cost bagi investor. Tingkat total akurasi yang dihasilkan adalah 89,29\% di mana lebih akurat dari model Altman, model Zmijewski memprediksi 14 perusahaan dengan tepat. Dengan kata lain, tidak terdapat kesalahan dalam memprediksi perusahaan dengan kondisi real mengalami financial distress. Artinya, dalam memprediksi perusahaan dengan kondisi real mengalami financial distress model Zmijewski memiliki eror tipe I sebesar 0\%. Begitu pula dengan kondisi sebaliknya, model Zmijewski mampu memprediksi benar 14 perusahaan dengan kondisi real tidak mengalami financial distress. Artinya, dalam memprediksi perusahaan dengan kondisi real tidak mengalami financial distress model Zmijewski memiliki eror tipe II sebesar $0 \%$. Secara keseluruhan, dari 28 perusahaan model Zmijewski benar memprediksi kondisi 28 perusaahan tersebut sehingga total akurasi model Zmijewski sebesar 100\%. Model Zmijewski berhasil memprediksi kondisi perusahaan dengan sempurna. Hal ini dapat disebabkan oleh sesuainya pemilihan rasio keuangan yang membentuk model dengan definisi financial distress dalam penelitian ini, yaitu Net Income / Total Asset, Total Liabilities / Total Asset dan Current Asset / Current Liabilities. Keseluruhan dari rasio ini adalah rasio-rasio yang mewakili ekuitas dan net income perusahaan. Hal inilah yang menjadi salah satu penyebab tingginya nilai akurasi dalam model Zmijewski. Menurut Husein \& Pambekti (2014) hal lain yang dapat kita lihat pada model Zmijewski adalah bahwa model 
Zmijewski menekankan besarnya utang dalam memprediksi kondisi financial distress perusahaan. Antara tiga rasio dalam model ada dua rasio yang dipengaruhi oleh utang. Semakin besar jumlah utang maka model akan memprediksi perusahaan mengalami financial distress. Hal ini juga menunjukkan perusahaan yang mengalami financial distress cenderung memiliki masalah pada leverage (TLTA) dan likuiditas (CACL). Berdasarkan semua penghitungan, dapat diketahui bahwa model Zmijewski merupakan model prediksi dengan tingkat akurasi paling tinggi yaitu sebesar 100\%. Menurut Husein \& Pambekti (2014) hal lain yang dapat kita lihat pada model Zmijewski adalah bahwa model Zmijewski menekankan besarnya utang dalam memprediksi kondisi financial distress perusahaan. Antara tiga rasio dalam model ada dua rasio yang dipengaruhi oleh utang. Semakin besar jumlah utang maka model akan memprediksi perusahaan mengalami financial distress. Hal ini juga menunjukkan perusahaan yang mengalami financial distress cenderung memiliki masalah pada leverage (TLTA) dan likuiditas (CACL).
Berdasarkan semua penghitungan, dapat diketahui bahwa model Zmijewski merupakan model prediksi dengan tingkat akurasi paling tinggi yaitu sebesar 100\%. Menurut Husein \& Pambekti (2014) hal lain yang dapat kita lihat pada model Zmijewski adalah bahwa model Zmijewski menekankan besarnya utang dalam memprediksi kondisi financial distress perusahaan. Antara tiga rasio dalam model ada dua rasio yang dipengaruhi oleh utang. Semakin besar jumlah utang maka model akan memprediksi perusahaan mengalami financial distress. Hal ini juga menunjukkan perusahaan yang mengalami financial distress cenderung memiliki masalah pada leverage (TLTA) dan likuiditas (CACL). Berdasarkan semua penghitungan, dapat diketahui bahwa model Zmijewski merupakan model prediksi dengan tingkat akurasi paling tinggi yaitu sebesar 100\%. Menurut Husein \& Pambekti (2014) hal lain yang dapat kita lihat pada model Zmijewski adalah bahwa model Zmijewski menekankan besarnya utang dalam memprediksi kondisi financial distress perusahaan. Antara tiga rasio dalam model ada dua rasio yang dipengaruhi oleh utang. 
Semakin besar jumlah utang maka model akan memprediksi perusahaan mengalami financial distress. Hal ini juga menunjukkan perusahaan yang mengalami financial distress cenderung memiliki masalah pada leverage (TLTA) dan likuiditas (CACL). Berdasarkan semua penghitungan, dapat diketahui bahwa model Zmijewski merupakan model prediksi dengan tingkat akurasi paling tinggi yaitu sebesar 100\%. Menurut Husein \& Pambekti (2014) hal lain yang dapat kita lihat pada model Zmijewski adalah bahwa model Zmijewski menekankan besarnya utang dalam memprediksi kondisi financial distress perusahaan. Antara tiga rasio dalam model ada dua rasio yang dipengaruhi oleh utang. Semakin besar jumlah utang maka model akan memprediksi perusahaan mengalami financial distress. Hal ini juga menunjukkan perusahaan yang mengalami financial distress cenderung memiliki masalah pada leverage (TLTA) dan likuiditas (CACL). Berdasarkan semua penghitungan, dapat diketahui bahwa model Zmijewski merupakan model prediksi dengan tingkat akurasi paling tinggi yaitu sebesar 100\%. Menurut Husein \&
Pambekti (2014) hal lain yang dapat kita lihat pada model Zmijewski adalah bahwa model Zmijewski menekankan besarnya utang dalam memprediksi kondisi financial distress perusahaan. Antara tiga rasio dalam model ada dua rasio yang dipengaruhi oleh utang. Semakin besar jumlah utang maka model akan memprediksi perusahaan mengalami financial distress. Hal ini juga menunjukkan perusahaan yang mengalami financial distress cenderung memiliki masalah pada leverage (TLTA) dan likuiditas (CACL). Berdasarkan semua penghitungan, dapat diketahui bahwa model Zmijewski merupakan model prediksi dengan tingkat akurasi paling tinggi yaitu sebesar 100\%. Menurut Husein \& Pambekti (2014) mengatakan bahwa hal lain yang dapat kita lihat pada model Zmijewski adalah bahwa model Zmijewski menekankan besarnya utang dalam memprediksi kondisi financial distress perusahaan. Antara tiga rasio dalam model ada dua rasio yang dipengaruhi oleh utang. Semakin besar jumlah utang maka model akan memprediksi perusahaan mengalami financial distress. Hal ini juga menunjukkan perusahaan yang 
mengalami financial distress cenderung memiliki masalah pada leverage (TLTA) dan likuiditas (CACL). Berdasarkan semua penghitungan, dapat diketahui bahwa model Zmijewski merupakan model prediksi dengan tingkat akurasi paling tinggi yaitu sebesar 100\%. kondisi financial distress perusahaan. Dari banyaknya rasio yaitu ada tiga rasio dalam model ada dua Berdasarkan semua penghitungan yang dilakukan oleh penulis di mana dapat diketahui bahwa model Zmijewski merupakan model prediksi dengan tingkat akurasi paling tinggi yaitu sebesar $100 \%$. Selanjutnya berturutturut diikuti oleh model Springate sebesar 89,29\% dan model Altman sebesar $75 \%$. Hal ini sejalan dengan penelitian yang dilakukan oleh Yami (2015), Syafitri \& Wijaya (2014), Husein \& Pambekti (2014) dan Rismawaty (2012).

Tabel 3 Total Perhitungan Dengan Menggunakan Altman, Springate dan Zmijewski

\begin{tabular}{cccc} 
Prediksi & Altman & Springate & Zmijewski \\
Distress & 14 & 13 & 14 \\
Non Distress & 7 & 12 & 14 \\
Total & 21 & 25 & 28 \\
\% Akurasi & $\mathbf{7 5 \%}$ & $\mathbf{8 9 , 2 9 \%}$ & $\mathbf{1 0 0 \%}$ \\
\hline
\end{tabular}

\section{SIMPULAN}

Penelitian ini bertujuan untuk menemukan bukti empiris terkait model prediksi yang paling akurat untuk memprediksi kondisi financial distress di perusahaan manufaktur yang terdaftar di Bursa Efek Indonesia pada periode 2011- 2014. Dari hasil pengujian empiris didapatkan kesimpulan di mana tingkat akurasi masing-masing model prediksi adalah $75 \%$ untuk model Altman, 89,29\% untuk model Springate dan 100\% untuk model Zmijewski. Berdasarkan tingkat akurasi tertinggi, model yang paling akurat dalam memprediksi kondisi financial distress 
di perusahaan manufaktur di Indonesia adalah model Zmijewski dengan tingkat akurasi $100 \%$. Penelitian ini tidak lepas dari keterbatasan-keterbatasan yang membatasi ruang lingkup penelitian. Jangka waktu penelitian yang diobservasi dibatasi untuk periode 2011-2014, dan model prediksi financial distress terbatas pada model Altman, Springate dan Zmijewski. Adapun saran yang mungkin bisa digunakan untuk menyempurnakan penelitian, bagi penelitian selanjutnya diharapkan jumlah sampel dan periode sebaiknya ada penambahan atau jenis perusahaan yang berbeda. Penelitian

\section{DAFTAR PUSTAKA}

Almilia, L. S. 2006. Prediksi Kondisi Financial Distress Perusahaan Go-Public Dengan Menggunakan Analisis Multinomial Logit. Jurnal Ekonomi dan Bisnis. vol. 12 no. 1.

Kristijadi. 2003. Analisis Rasio Keuangan Untuk Memprediksi Kondisi Financial Distress

Perusahaan Manufaktur Yang Terdaftar Di Bursa Efek Jakarta. Jurnal Akuntasi dan Auditing Indonesia, vol. 7 no. 2, p. 183210. selanjutnya bisa menggunakan kriteria financial distress yang berbeda. Penelitian selanjutnya dapat menggunakan model-model prediksi lain yang ada, seperti model Ohlson, Fulmer, Grover, Zavgren, CA Score dan model lainnya. Bagi Investor dan Manajemen Perusahaan, dari hasil perhitungan tingkat akurasi dari ketiga model yang menunjukan bahwa model Zmijewski memiliki tingkat akurasi tertinggi, maka sebaiknya investor dan pihak perusahaan menggunakan model Zmijewski untuk memprediksi kondisi financial distress perusahaan.

Altman, E. E. 1968. Financial Ratios, Discriminant Analysis and The Prediction of Corporate Bankruptcy. The Journal of Finance. vol. 23 no. 4, p. 589609.

Christianti, A. 2013. Akurasi

Prediksi Financial Distress: Perbandingan Model Altman dan Ohlson. Jurnal Ekonomi dan Bisnis, vol. 7 no. 2, p. 7789. 
Gamayuni, R. R. 2011. Analisis

Ketepatan Model Altman sebagai Alat untuk Memprediksi Kebangkrutan (Studi Empiris pada Perusahaan Manufaktur di BEI). Jurnal Akuntansi dan Keuangan, vol. 16 no. 2, p.158176.

Hadi, S., dan Anggraeni, A. 2008.

Pemilihan Prediktor Delisting Terbaik (Perbandingan Antara The Zmijewski Model, The Altman Model, dan The Springate Model). Jurnal Akuntansi dan Auditing Indonesia, vol. 12 no. 2.

Hery. 2015. Praktis Menyusun

Laporan Keuangan. Jakarta: Grasindo.

Husein, M. F., and Pambekti, G. T. 2014. Precision of the Models of Altman, Springate, Zmijewski, and Grover for Predicting the Financial Distress. Journal of Economics, Business, and Accountancy Vantura. Vol 17. No 3, p.405-416.

Ikatan Akuntansi Indonesia. 2009.

Pernyataan Standar Akuntansi

Keuangan. Jakarta: Salemba Empat.

Jogiyanto. 2008. Metodologi

Penelitian; Sistem Informasi. Yogyakarta: BPFE- Yogyakarta.

Platt, H. D., and Platt, M. B. 2002.

Predicting Corporate Financial Distress: Reflections on ChoiceBased Sample Bias. Journal of Economic and Finance, vol. 26 no. 2, p.184-199.
Purnajaya, K. D., dan Merkusiwati, N. K. 2014. Analisis Komparasi Potensi Kebangkrutan Dengan Motode Z-Score Altman, Springate, Dan Zmijewski Pada Perusahaan Industri Kosmetik Yang Terdaftar di Bursa Efek Indonesia. E-Jurnal Akuntansi Universitas Udayana, vol. 7 no. 1, p. 48-63.

Ramadhani, A. S., dan Lukviarman, N. 2009. Perbandingan Analisis Prediksi Kebangkrutan Menggunakan Model Altman Pertama, Altman Revisi, dan Altman Modifikasi Dengan Ukuran dan Umur Perusahaan Sebagai Variabel Penjelas (Studi Pada Perusahaan Manufaktur Yang Terdaftar Di Bursa Efek Indonesia). Jurnal Siasat Bisnis Vol. 13 No. 1, p. 15-28.

Ross, S. A., Westerfield, R., and Jaffe. 2003. Corporate Finance. Sixth Edition.

United States of America: The McGraw-Hill Companies, Inc.

Sondakh, C. A., Murni, S., dan Mandagie, Y. 2014. Analisis Potensi Kebangkrutan Dengan Menggunakan Metode Altman Z-Score, Springate dan Zmijewski Pada Industri Perdagangan Ritel Yang Terdaftar di BEI Periode 20092013. Jurnal Riset Ekonomi, Manajemen, Bisnis dan Akuntansi. Vol. 2, No. 4, p. 364373. 
Suliyanto. 2009. Metode Riset

Bisnis. Yogyakarta: ANDI.

Sunyoto, D. 2013. Analisis Laporan

Keuangan Untuk Bisnis (Teori dan Kasus). Yogyakarta: Center of Academic Publishing Service.

Trihendradi, C. 2013. Langkah

Mudah Menguasai SPSS 21. Yogyakarta: ANDI Wild, J.

J., Subramanyam, K. R., and Halsey,

R. F. 2008. Financial Statement Analysis (Analisis Laporang Keuangan). Edisi 8. Buku Satu. Jakarta: Salemba Empat.

Zmijewski, M. E. 1984.

Methodological Issues Related to the Estimation of Financial Distress Prediction Models. Journal of Accounting Research. vol. 22, p. 59-82. 